\title{
EFFECT OF PRECEDING CROPS, TILLAGE AND WEED CONTROL TREATMENTS ON GROWTH CHECKED AND ASSOCIATED WEED CHARACTERS OF $\left(\begin{array}{c}\text { against plagian } \\ \text { using } \\ \text { TurnitIn }\end{array}\right.$ CORN \\ Attia, A.N. ; S.A. EL-Moursy and O.J. Fatah \\ Agronomy Department, Faculty of Agriculture, Mansoura \\ University, Egypt.
}

\begin{abstract}
The field experiment was carried out at the Experimental Station Farm in Agronomy Department, Faculty of Agriculture, Mansoura University, during 2014 and 2015 seasons to determine the effect of preceding crops, tillage and weed control treatments as well as their interactions on growth and associated weed characters of corn (Zea mays L.) Single Cross Giza 168 yellow (S.C. 168). Each preceding winter crop (wheat, Egyptian clover and filed bean) treatment was carried out in separate experiment. Every experiment of preceding crop was conducted in strip-plot design with three replications. The obvious results of this investigation can be summarized as follows:

Sowing field bean as a preceding crop of corn exceeded other preceding crops and produced the highest values of all studied characters over both seasons.

The highest values of corn growth characteristics and the minimum values of fresh and dry weights of total weeds $/ \mathrm{m}^{2}$ were achieved by using chisel plow twice.

The maximum averages of growth characteristics were achieved as a result of controlling the growing weeds in corn field by hoeing two times before the first and second irrigations (after 21 and 35 days from sowing). Two hoeings treatment more effective than other studied weed control treatments in striving weeds, subsequently significantly decreased fresh and dry weights of total weeds $/ \mathrm{m}^{2}$ and produced the lowest values.

Finally, it can be concluded that sowing field bean or Egyptian clover as preceding crops before corn and tillage field by using the chisel plow twice besides controlling weeds growing in field by hoeing twice in order to maximize growth at the same time reduce weeds competition under the environmental conditions of Dakahlia Governorate, Egypt.

Key words: Corn, Maize, Preceding Crops, Tillage, Non-tillage, Hoeing, Herbicides, Growth, Weed Characters.
\end{abstract}

\section{INTRODUCTION}

Maize or corn (Zea mays L.) production has become very popular and the crop is widely grown in many countries in the world. Corn is not only an important human nutrient, but also a basic element of animal feed whether fresh, silage or grains and raw material for manufacture of many industrial products.

Benefits of crop rotations have been known for thousands of years as to increase organic matter in the soil, improves soil structure, reduces soil degradation, helps in weed control and can result in higher yields and greater farm profitability in the long-term, though these benefits have changed over time as technology develops. Rotating corn and legume crops like clover and field bean has been used as a management tool to increase crop yields 
(Pedersen and Lauer, 2004). Arif et al. (2011) showed that legume-cereal (chickpea-maize) cropping system resulted in the highest values of ear length and weight, number of grains/ear, grains weight/ear and grain and stover yields, However, these characters were minimal for cereal-cereal (wheatmaize) cropping system. Bezuidenhout et al. (2012) indicated that the emergence and early growth of maize were delayed in the presence of physical residues of both preceding crop, in particular annual ryegrass. Bharathi et al. (2013) demonstrated that when suggested recommendations of nitrogen fertilizer, it is necessary to consider cropping sequence, because the need for nutrients by crop would vary depending upon the preceding crop type and its inputs usage. Yeganehpoor et al. (2013) reported that among preceding crops, the cultivation of clover before maize had the highest values of growth traits as compared to other treatments (hairy vetch, basil and dill).

Tillage has been chief aspect of technological development in the evolution of agriculture, in particular in food production. The objectives of tillage the soil involves; seedbed preparation, water and soil conservation besides weed control. Tillage also has various physical, chemical and biological effects on the soil. The physical effects such as aggregate-stability, infiltration rate, soil and water conservations, consequently have a direct effect on soil productivity and yield sustainability, which led to an enhanced nutrient uptake and better yield of field crops (Arif et al., 2007). Abd-Rabboh (2013) revealed that there were substantial differences in all studied characters i.e. plant and ear height, stem diameter, and ear leaf area among tillage treatments in both seasons. Wlaiwan and Jayasuriya (2013) showed that tillage treatment i.e. sub-soiler tillage (ST), three methods of conventional tillage (CT1, CT2 and CT3), no-tillage (NT) showed significant effect on physical and chemical soil properties, plant growth and development of maize as well as total biomass of weeds. Lu et al. (2015) concluded that conservation-focused tillage systems, i.e., no tillage, could be reduced yields, thus produced better yields and provide environmentally friendly options.

The weeds are considered as a foremost problem in maize fields, which causes 35-40 \% yield losses (Dogan et al., 2003). Weed control through mechanical methods like hoeing is still a traditional method for weed control. However, use of mechanical weed control via hoeing demands experience and knowledge of how to use the soil as a weed controlling agent. Bezuidenhout et al. (2012) pointed out that weed management strategy including the mulch retained on the soil surface, with a possible reduction in the type and amount of herbicide could be used to achieve effective weed control. Khan et al. (2012) found that the lowest weed density and the lowest dry weight of weed resulted from plots sprayed with atrazine. Takim et al. (2012) showed that the plots that were hoeing twice or treated with $2 \mathrm{~kg}$ a.i $\mathrm{ha}^{-1}$ of Lasset and Huricane herbicides significantly produced higher grain yield. Kandil and Kordy (2013) showed the combination between hand hoeing with pre- and post- emergency herbicides led to the most effective way for controlling weeds and thus increasing maize growth characters. Nassar (2013) stated that weed control treatments (atrazine with one hand hoeing, hand hoeing twice and atrazine only as pre emergence herbicide) had higher 
growth characters as compared to un-weeded treatment. All weed control treatments significantly decreased total number, fresh and dry weights of weeds as compared with un-weeded check. Yeganehpoor et al. (2013) revealed that the maize weed control treatment by hoeing a companied with higher values of growth characters as compared to not hoeing of weeds.

Thus, this investigation was aimed to study the effect of preceding crops, tillage and weed control treatments on growth and associated weed characters of corn Single Cross Giza 168 yellow (S.C. 168) under the environmental conditions of Dakahlia Governorate, Egypt.

\section{MATERIALS AND METHODS}

The field experiment was carried out at the Experimental Station Farm in Agronomy Department, Faculty of Agriculture, Mansoura University, during 2014 and 2015 seasons to determine the effect of preceding crops, tillage and weed control treatments as well as their interactions on growth and associated weed characters of yellow corn (Zea mays L.) Single Cross Giza 168 (S.C. 168).

Each preceding winter crop (wheat, Egyptian clover and filed bean) treatment was carried out in separate experiment. Every experiment of preceding crop was conducted in strip-plot design with three replications.

The vertical plots were assigned to two tillage treatments (tillage and nontillage). In the tillage treatment, the experimental field was tillage using chisel plow twice to reach the depth of 30 , and each experimental basic unit is terrace, included three ridges, each of $70 \mathrm{~cm}$ width and $3.0 \mathrm{~m}$ length, resulted an area of $\left(2.1 \times 3.0=6.3 \mathrm{~m}^{2}\right)$. While, in the non-tillage treatment, the experimental field was left without tillage after the previous preceding winter crops, and each experimental basic unit included three ridges, each of $70 \mathrm{~cm}$ width and $3.0 \mathrm{~m}$ length, resulted an area of $\left(2.1 \times 3.0=6.3 \mathrm{~m}^{2}\right)$ also.

The horizontal plots were occupied with the following three weed control treatments:

1- Hoeing treatment. The growing weeds in corn field were controlled by hoeing two times before the first and second irrigations (after 21 and 35 days from sowing).

2- Herbicide treatment. The growing weeds in corn field were controlled by using Atrazine herbicide ( $50 \% \mathrm{WP})$ at the rate of $0.75 \mathrm{~kg} / \mathrm{fed}$ as preemergence of weeds.

3- Without weed control (control treatment).

Atrazine [6-chloro- $\mathrm{N}$-ethyl $\mathrm{N}^{\prime}$-(1-methylethyl)-triazine-2,4-diamine] is a selective systemic herbicide, absorbed principally through the roots, but also through the foliage, with translocation acropetally in the xylem and accumulation in the apical meristems and leaves of weeds.

Soil samples were taken at random from the experimental field area before sowing at a depth of $0-20 \mathrm{~cm}, 20-40 \mathrm{~cm}$ and $40-60 \mathrm{~cm}$ from soil surface during the two growing seasons to measure the physical and chemical soil properties as shown in Table 1. 
Table 1: Physical and chemical soil characteristics ${ }^{*}$ at the experimental sites before sowing over both seasons.

\begin{tabular}{|c|c|c|c|c|c|c|c|c|c|c|}
\hline \multirow{2}{*}{\multicolumn{2}{|c|}{ Soil analysis }} & \multicolumn{3}{|c|}{ Wheat } & \multicolumn{3}{|c|}{ Egyptian clover } & \multicolumn{3}{|c|}{ Filed bean } \\
\hline & & $\begin{array}{l}0-20 \\
\mathrm{~cm}\end{array}$ & $\begin{array}{c}20-40 \\
\mathrm{~cm}\end{array}$ & $\begin{array}{c}40-60 \\
\mathrm{~cm}\end{array}$ & $\begin{array}{l}0-20 \\
\mathrm{~cm}\end{array}$ & $\begin{array}{c}20-40 \\
\mathrm{~cm}\end{array}$ & $\begin{array}{c}40-60 \\
\mathrm{~cm}\end{array}$ & $\begin{array}{c}0-20 \\
\mathrm{~cm}\end{array}$ & $\begin{array}{c}20-40 \\
\mathrm{~cm}\end{array}$ & $\begin{array}{c}40-60 \\
\mathrm{~cm}\end{array}$ \\
\hline \multicolumn{11}{|c|}{ A: Physical analysis: } \\
\hline \multicolumn{2}{|l|}{ Sand \% } & 26.2 & 27.9 & 26.4 & 25.4 & 28.5 & 30.5 & 25.3 & 27.9 & 24.4 \\
\hline \multicolumn{2}{|l|}{ Silt \% } & 35.5 & 37.3 & 32.4 & 33.5 & 37.3 & 39.1 & 34.2 & 37.8 & 31.4 \\
\hline \multicolumn{2}{|c|}{ Clay \% } & 38.3 & 34.8 & 41.2 & 41.1 & 34.2 & 30.4 & 40.5 & 34.3 & 44.2 \\
\hline \multicolumn{11}{|c|}{ B: Chemical analysis: } \\
\hline \multirow{3}{*}{$\begin{array}{l}\text { Available } \\
\mathrm{mg} / \mathrm{kg}\end{array}$} & $\mathrm{N}$ & 59.1 & 54.1 & 60.7 & 62.3 & 51.1 & 51.2 & 60.2 & 59.1 & 67.5 \\
\hline & $P$ & 10.9 & 9.4 & 9.9 & 13.3 & 9.2 & 7.5 & 9.9 & 9.8 & 12.2 \\
\hline & $\mathrm{K}$ & 339 & 299 & 351 & 423 & 316 & 284 & 345 & 342 & 389 \\
\hline \multirow{4}{*}{$\begin{array}{l}\text { Soluble } \\
\text { cations } \\
\text { meq/L }\end{array}$} & $\mathrm{Ca}^{++}$ & 1.62 & 1.71 & 1.78 & 1.23 & 1.33 & 1.42 & 0.89 & 0.98 & 0.99 \\
\hline & $\mathrm{Mg}^{++}$ & 1.17 & 1.25 & 1.35 & 0.81 & 0.87 & 0.95 & 0.57 & 0.63 & 0.67 \\
\hline & $\mathrm{Na}^{+}$ & 4.87 & 5.81 & 5.47 & 3.66 & 3.89 & 4.02 & 2.39 & 2.47 & 2.55 \\
\hline & $\mathrm{K}^{+}$ & 0.40 & 0.44 & 0.42 & 0.28 & 0.34 & 0.35 & 0.19 & 0.26 & 0.28 \\
\hline \multirow{4}{*}{$\begin{array}{l}\text { Soluble } \\
\text { anions } \\
\text { meq/L }\end{array}$} & $\mathrm{CO}_{3}{ }^{--}$ & - & - & - & - & - & - & - & - & - \\
\hline & $\mathrm{HCO}_{3}{ }^{-}$ & 1.73 & 1.78 & 1.90 & 1.26 & 1.41 & 1.51 & 0.99 & 0.99 & 1.30 \\
\hline & $\mathrm{Cl}^{-}$ & 4.45 & 4.73 & 5.01 & 3.30 & 3.53 & 3.76 & 2.67 & 2.86 & 2.99 \\
\hline & $\mathrm{SO}_{4}$ & 1.91 & 1.96 & 2.24 & 1.41 & 1.40 & 1.56 & 0.91 & 1.12 & 1.16 \\
\hline \multicolumn{2}{|l|}{$\mathrm{pH}$} & 7.92 & 7.86 & 7.78 & 7.70 & 7.64 & 7.69 & 8.12 & 8.09 & 8.06 \\
\hline \multicolumn{2}{|l|}{$\mathrm{EC} \mathrm{ds} / \mathrm{m}$} & 1.58 & 1.65 & 1.79 & 1.17 & 1.21 & 1.28 & 0.91 & 0.99 & 0.98 \\
\hline
\end{tabular}

* Soil and Water Analysis Institute, Mansoura Lab., Agricultural Research Center (ARC).

Calcium superphosphate $\left(\begin{array}{llll}15.5 & \% & \mathrm{P}_{2} \mathrm{O}_{5}\end{array}\right)$ was applied during soil preparation in the tillage treatment and before sowing in the non-tillage treatment at the rate of $150 \mathrm{~kg} / \mathrm{fed}$. Corn grains were hand sown in hills 25 $\mathrm{cm}$ apart of each ridge at the rate of $2-3$ grains/hill using dry sowing method (Afir) during last week of April in both seasons. The plants were thinned to one plant per hill before the first irrigation. The first irrigation was applied after 21 days from sowing and the following irrigations were applied at 15 days intervals during the growing seasons. Nitrogen fertilizer in the form of ammonium nitrate $(33.5 \% \mathrm{~N})$ was added at the rate of $120 \mathrm{~kg} \mathrm{~N} / \mathrm{fed}$ in two equal parts, one half after thinning (before the first irrigation) and the other half before the second irrigation. Potassium sulphate $\left(48 \% \mathrm{~K}_{2} \mathrm{O}\right)$ at the rate of $50 \mathrm{~kg} / \mathrm{fed}$ was applied at the first dose of nitrogen fertilizer. The other agricultural practices were kept the same as normally practiced in corn fields according to the recommendations of Ministry of Agriculture and Land Reclamation, except for the factors under study.

\section{Studied Characters:}

\section{A- Growth Characters:}

After 100 days from sowing, samples of five plants were taken at random from each plot to determine the following characters:

1- Plant height $(\mathbf{c m})$ : It was measured in $\mathrm{cm}$ from the soil surface up to the node of tassel.

2- Ear height (cm): It was measured in $\mathrm{cm}$ from the soil surface up to the shank of the first ear. 
3- Stalks diameter (cm): It was measured in $\mathrm{cm}$ by using a varnier caliper on the third internode of the stalks above the soil surface.

4- Ear leaf area $\left(\mathrm{cm}^{2}\right)$ : It was calculated by the following formula according to Gardner et al. (1985):

Ear leaf area $=$ Ear leaf length $\times$ maximum width of ear leaf $\times 0.75$

B- Weed Characters:

5- Fresh weight of total weeds $/ \mathrm{m}^{2}(\mathrm{~g})$. It was recorded after cleaned and then weighted as grams per square meter.

6- Dry weight of total weeds $/ \mathrm{m}^{2}(\mathrm{~g})$. It was recorded after dried weeds at $105^{\circ} \mathrm{C}$ for 48 hours.

\section{Statistical analysis}

All obtained data were statistically analyzed according to the technique of analysis of variance (ANOVA) for the strip - plot design to each experiment (preceding crop), then combined analysis was done between preceding crop experiments and over seasons as published by Gomez and Gomez (1984) by using "MSTAT-C " computer software package. New Least Significant of Difference (NLSD) method was used to test the differences between treatment means at $5 \%$ level of probability as described by Snedecor and Cochran (1980).

\section{RESULTS AND DISCUSSION}

\section{I- Effect of preceding crops:}

The effect of preceding crops i.e. wheat, Egyptian clover and filed bean on corn growth characters i.e. plant height $(\mathrm{cm})$, ear height $(\mathrm{cm})$, stalks diameter $(\mathrm{cm})$ and ear leaf area $\left(\mathrm{cm}^{2}\right)$ was significant over both seasons (Table 2). From obtained results, it could be recommend that sowing field bean as a preceding crop of corn, which exceeded other preceding crops and produced the highest values of these characters over both seasons. However, sowing Egyptian clover in winter season as preceding crop of corn came in the second rank after aforementioned treatment. While, the lowest values of these characters were resulted from sowing wheat in winter season as preceding crop of corn. These results may be due to legumes especially field bean and Egyptian clover are widely recognized as a good builders of soil fertility and contribute substantial amounts of nitrogen for sustainability of corn (Pedersen and Lauer, 2004). Thus, field bean increased soil fertility and accordingly the growth characters of corn such as plant height. Arif et al. (2011), Bezuidenhout et al. (2012), Bharathi et al. (2013) and Yeganehpoor et al. (2013) came out similar results.

Studied preceding crops showed significant effect on weed characters (fresh weight of total weeds $/ \mathrm{m}^{2}(\mathrm{~g})$ and dry weight of total weeds $/ \mathrm{m}^{2}(\mathrm{~g})$ over both seasons (Table 3 ). The minimum values of weed characters were achieved from sowing field bean as a preceding crop of corn. The arrangement of preceding crops after field bean was Egyptian clover then wheat with respect to their desirable effect on these traits during the growing season. This reduction in fresh weight of total weeds $/ \mathrm{m}^{2}$ owing to sowing field bean as a preceding crop may be attributed to the improvement of corn growth and increasing competition between corn and weeds in favor of corn. 


\section{ii- Effect of tillage treatments:}

Regarding the effect of tillage treatments on corn growth characteristics i.e. plant height $(\mathrm{cm})$, ear height $(\mathrm{cm})$, stalks diameter $(\mathrm{cm})$ and ear leaf area $\left(\mathrm{cm}^{2}\right)$, the obtained results of this study apparently cleared that there was a significant effect, except stalks diameter over both seasons (Table 2). It could be noticed that the highest values of corn growth characteristics were achieved by using chisel plow twice. Adversely, the lowest values of these characters were resulted from non-tillage treatment over both seasons. The increases in growth characteristics due to tillage using chisel plow twice may be ascribed to weaken the soil strength, reduce compaction and allow the free movement of air and water. Also, this tillage treatment was carried with the objective of changing the soil physical properties and to enable the plant to show their full potential in order to promote plant growth (Arif et al., 2007). These results are in coincidence with those reported by Abd-Rabboh (2013). Tillage treatments had a significant effect on weed characters (fresh weight of total weeds $/ \mathrm{m}^{2}$ and dry weight of total weeds $/ \mathrm{m}^{2}$ ) over both seasons (Table 3). The maximum values of fresh and dry weights of total weeds $/ \mathrm{m}^{2}$ were produced by non-tillage over both seasons. Whilst, the minimum values of fresh and dry weights of total weeds $/ \mathrm{m}^{2}$ were given by using the chisel plow twice in order to tillage corn soil over both seasons. The drop in fresh weight of total weeds $/ \mathrm{m}^{2}$ owing to tillage using chisel plow twice may be attributed to good tillage treatments not only kills weeds, but also enhances physical soil properties as well as tillage provide environmentally friendly options in controlling weeds (Lu et al., 2015).

\section{lii- Effect of weed control treatments:}

Weed control treatments i.e. hoeing, herbicide and without weed control exhibited significant effect on corn growth characters i.e. plant height $(\mathrm{cm})$, ear height $(\mathrm{cm})$, stalks diameter $(\mathrm{cm})$ and ear leaf area $\left(\mathrm{cm}^{2}\right)$ over both seasons (Table 2). The maximum averages of these characters were achieved as a result of controlling the growing weeds in corn field by hoeing two times before the first and second irrigations (after 21 and 35 days from sowing). Controlling the growing weeds in corn field by using Atrazine herbicide (50\% WP) at the rate of $0.75 \mathrm{~kg} / \mathrm{fed}$ as pre-emergence of weeds ranked secondly after hoeing treatment. On the other side, the lowest values of corn growth characters were resulted from control treatment (without hoeing). The increase in plant height associated with controlling the growing weeds in corn field by hoeing two times may be ascribed to more efficient in weed control, takedown soil around plants and then increasing root system consequently improvement corn growth measurements. These results stand in harmony with those obtained by Kandil and Kordy (2013) and Nassar (2013).

Weed control treatments i.e. hoeing, herbicide and without weed control had a significant effect on weed characters (fresh weight of total weeds $/ \mathrm{m}^{2}$ and dry weight of total weeds $/ \mathrm{m}^{2}$ ) over both seasons (Table 3). Two hoeings treatment more effective than other studied weed control treatments in striving weeds, subsequently significantly decreased fresh and dry weights of total weeds $/ \mathrm{m}^{2}$ and produced the lowest values. Whilst, control treatment (without weed control) gave the highest values of fresh and dry 
weights of total weeds $/ \mathrm{m}^{2}$ over both seasons. Such reduction in fresh weight of total weeds $/ \mathrm{m}^{2}$ by controlling weed by controlling the growing weeds in corn field by hoeing or Atrazine herbicide may be reflected to high efficiency of these methods in weed control. These results stand in harmony with those obtained by Nassar (2013).

Table 2: Plant and ear heights, stalk diameter and ear leaf area of maize as affected by preceding crops, tillage and weed control treatments as well as their interactions over both 2014 and 2015 seasons.

\begin{tabular}{|c|c|c|c|c|}
\hline $\begin{array}{l}\text { Characters } \\
\text { Treatments }\end{array}$ & $\begin{array}{l}\text { Plant height } \\
\text { (cm) }\end{array}$ & $\begin{array}{l}\text { Ear height } \\
\text { (cm) }\end{array}$ & $\begin{array}{c}\text { Stalk diameter } \\
(\mathrm{mm})\end{array}$ & $\begin{array}{c}\text { Ear leaf area } \\
\left(\mathrm{cm}^{2}\right)\end{array}$ \\
\hline \multicolumn{5}{|c|}{ A- Preceding crops: } \\
\hline Wheat & 219.9 & 131.1 & 16.70 & 693.2 \\
\hline Egyptian clover & 230.7 & 138.0 & 16.80 & 727.1 \\
\hline Field bean & 239.3 & 141.3 & 17.65 & 788.6 \\
\hline F. test & * & * & * & * \\
\hline NLSD at $5 \%$ & 16.0 & 6.0 & 0.78 & 38.8 \\
\hline \multicolumn{5}{|c|}{$B$ - Tillage treatments: } \\
\hline Tillage & 236.9 & 142.0 & 17.08 & 741.1 \\
\hline Non-tillage & 223.1 & 131.6 & 17.01 & 731.5 \\
\hline F. test & ${ }^{*}$ & ${ }^{*}$ & NS & ${ }^{*}$ \\
\hline \multicolumn{5}{|c|}{ C- Weed control treatments: } \\
\hline Hoeing & 231.8 & 140.0 & 17.68 & 764.5 \\
\hline Herbicide & 231.3 & 138.0 & 16.80 & 729.2 \\
\hline Without & 226.9 & 132.4 & 16.67 & 715.2 \\
\hline F. test & ${ }^{*}$ & ${ }^{*}$ & ${ }^{*}$ & ${ }^{*}$ \\
\hline NLSD at $5 \%$ & 4.1 & 5.4 & 0.42 & 43.7 \\
\hline \multicolumn{5}{|l|}{$D$ - Interactions: } \\
\hline$A \times B$ & NS & NS & NS & NS \\
\hline$A \times C$ & NS & NS & NS & NS \\
\hline$B \times C$ & NS & * & NS & ${ }^{*}$ \\
\hline$A \times B \times C$ & NS & NS & NS & * \\
\hline
\end{tabular}

\section{Iv- Effect of interactions:}

Statistical analysis of obtained data show that fresh and dry weights of total weeds $/ \mathrm{m}^{2}$ was significantly affected due to the interaction between preceding crops and weed control treatments over both seasons. The best results was resulted from sowing field bean in winter season as preceding crop of corn and controlling the growing weeds in corn field by hoeing two times before the first and second irrigations as graphically illustared in Figs. 1 and 2 .

With respect to the interaction effect between tillage treatments and weed control treatments, it was significant on ear height and ear leaf area over both seasons. The highest means of these traits were resulted from preparing corn field by using the chisel plow twice in order to tillage and controlling weeds in corn fields by hoeing twice as graphically illustared in Figs. 3 and 4. 
Concerning the third interaction among studied factors i.e. preceding crops, tillage treatments and weed control treatments, it exhibited significant effect on ear leaf area, fresh weight of total weeds $/ \mathrm{m}^{2}$ and dry weight of total weeds $/ \mathrm{m}^{2}$ over both seasons. The best results was resulted from sowing field bean as preceding crop before corn and tillage field by using the chisel plow twice besides controlling weeds growing in field by hoeing twice as graphically illustared in Figs. 5, 6 and 7 .

It can be concluded that sowing field bean or Egyptian clover as preceding crops before corn and tillage field by using the chisel plow twice besides controlling weeds growing in field by hoeing twice in order to maximize growth at the same time reduce weeds competition under the environmental conditions of Dakahlia Governorate, Egypt.

Table 3: Fresh and dry weights of total weeds $/ \mathrm{m}^{2}$ that found in maize field as affected by preceding crops, tillage and weed control treatments as well as their interactions during 2014 season.

\begin{tabular}{|c|c|c|}
\hline Treatments & $\begin{array}{l}\text { Fresh weight of total } \\
\text { weeds } / \mathrm{m}^{2} \\
(\mathrm{~g})\end{array}$ & $\begin{array}{l}\text { Dry weight of total } \\
\text { weeds } / \mathrm{m}^{2} \\
(\mathrm{~g})\end{array}$ \\
\hline \multicolumn{3}{|l|}{ A- Preceding crops: } \\
\hline Wheat & 140.4 & 38.12 \\
\hline Egyptian clover & 132.7 & 36.14 \\
\hline Field bean & 111.0 & 35.18 \\
\hline F. test & * & * \\
\hline NLSD at $5 \%$ & 15.6 & 2.74 \\
\hline \multicolumn{3}{|l|}{$B$ - Tillage treatments: } \\
\hline Tillage & 108.8 & 29.18 \\
\hline Non-tillage & 147.2 & 43.78 \\
\hline F. test & * & * \\
\hline \multicolumn{3}{|c|}{ C- Weed control treatments: } \\
\hline Hoeing & 81.8 & 23.12 \\
\hline Herbicide & 135.8 & 40.69 \\
\hline Without & 166.4 & 45.63 \\
\hline F. test & ${ }^{*}$ & * \\
\hline NLSD at $5 \%$ & 28.2 & 3.85 \\
\hline \multicolumn{3}{|l|}{$D$ - Interactions: } \\
\hline$A \times B$ & NS & NS \\
\hline$A \times C$ & * & * \\
\hline $\mathrm{B} \times \mathrm{C}$ & NS & NS \\
\hline$A \times B \times C$ & * & * \\
\hline
\end{tabular}




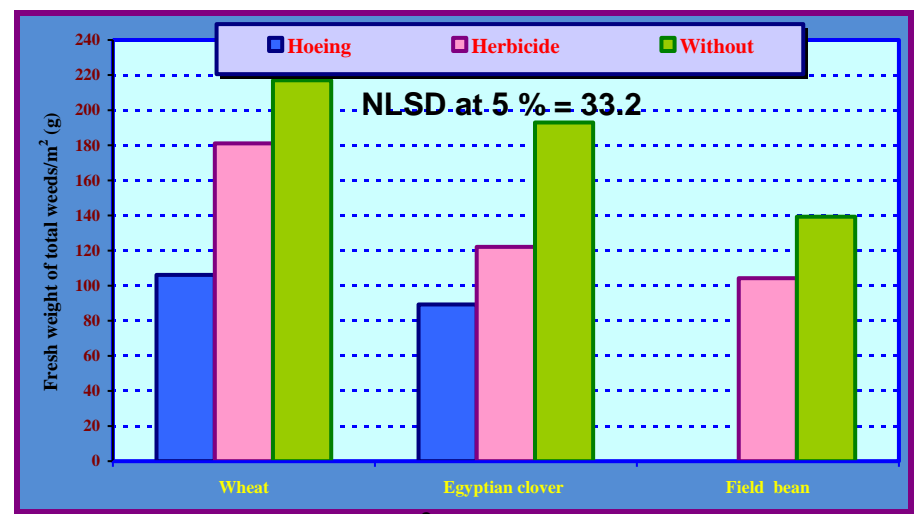

Fig. 1: Fresh weight of total weeds $/ \mathrm{m}^{2}(\mathrm{~g})$ as affected by the interaction between preceding crops and weed control treatments over both seasons.

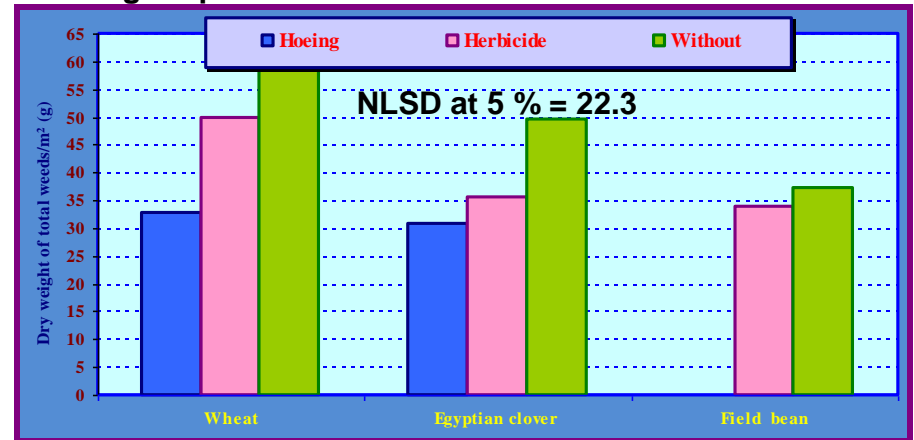

Fig. 2: Dry weight of total weeds $/ \mathrm{m}^{2}(\mathrm{~g})$ as affected by the interaction between preceding crops and weed control treatments over both seasons.

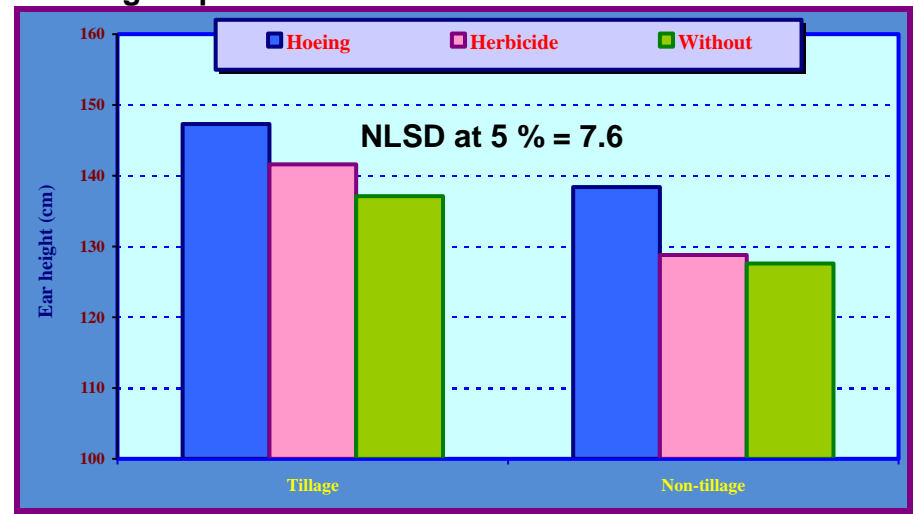

Fig. 3: Ear height $(\mathrm{cm})$ of corn as affected by the interaction between tillage and weed control treatments over both seasons. 


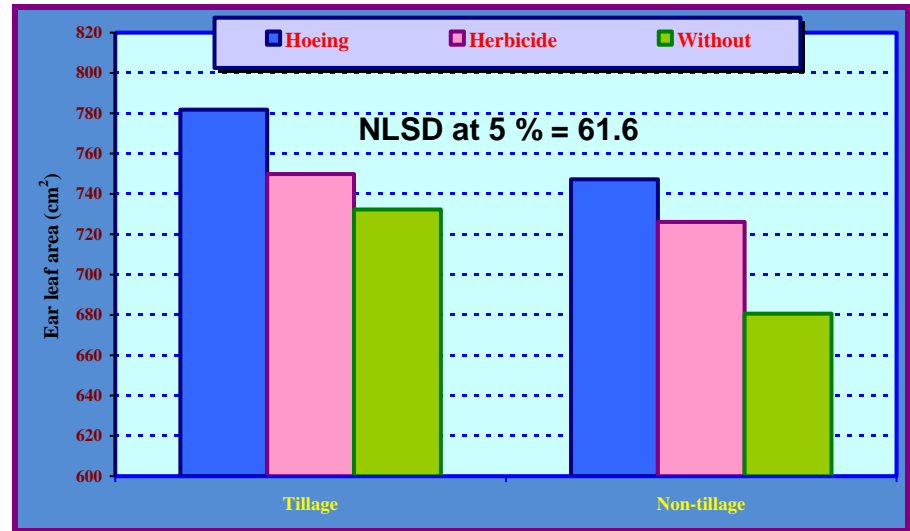

Fig. 4: Ear leaf area $\left(\mathrm{cm}^{2}\right)$ of corn as affected by the interaction between tillage and weed control treatments over both seasons.

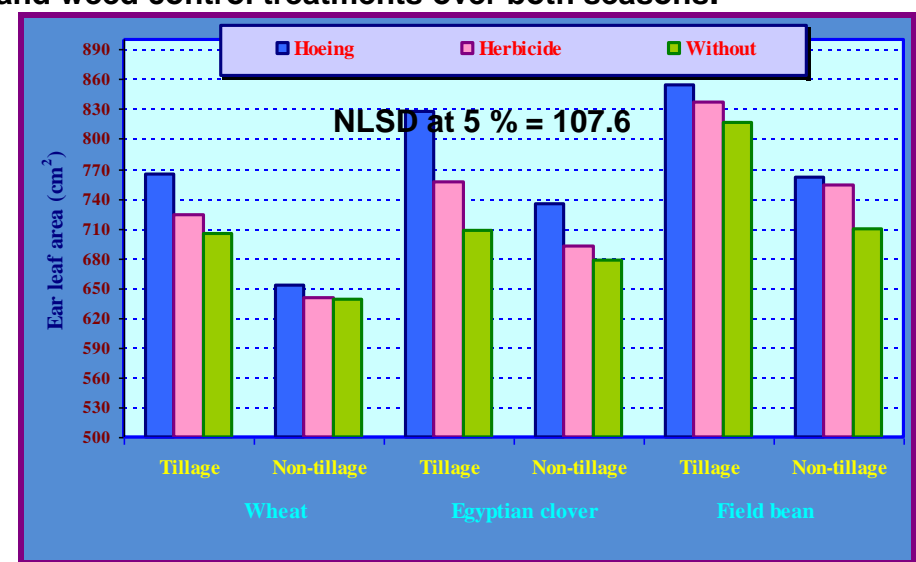

Fig. 5: Ear leaf area $\left(\mathrm{cm}^{2}\right)$ of corn as affected by the interaction among preceding crops, tillage and weed control treatments over both seasons.

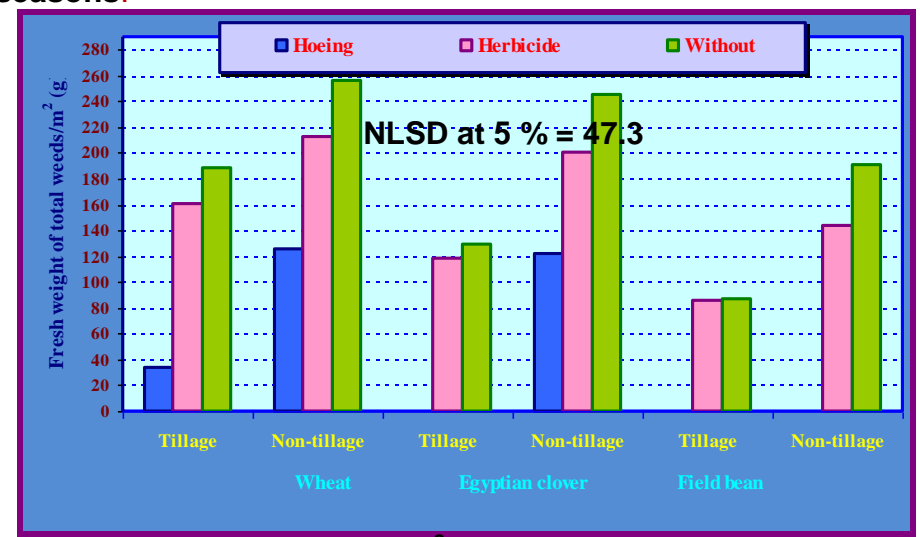

Fig. 6: Fresh weight of total weeds $/ \mathrm{m}^{2}(\mathrm{~g})$ as affected by the interaction among preceding crops, tillage and weed control treatments over both seasons. 


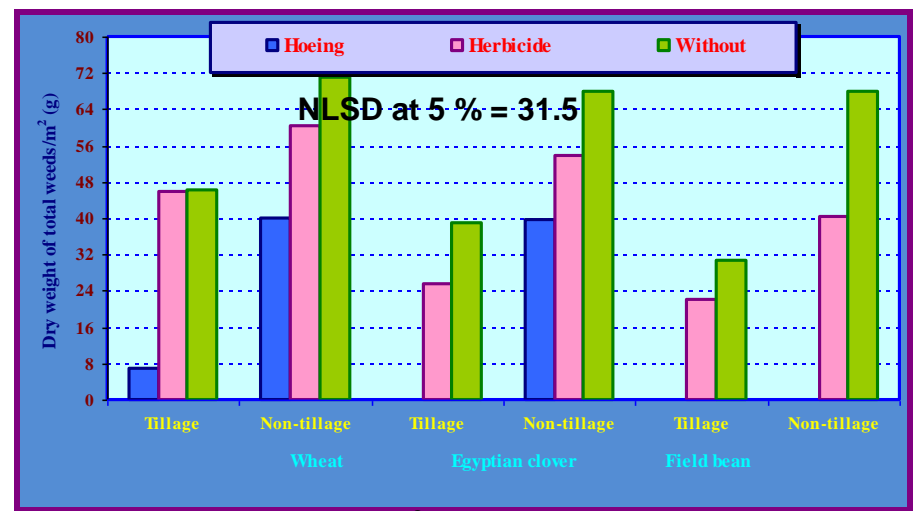

Fig. 7: Dry weight of total weeds $/ \mathrm{m}^{2}(\mathrm{~g})$ as affected by the interaction among preceding crops, tillage and weed control treatments over both seasons.

\section{REFERENCES}

Abd-Rabboh, A.M.K. (2013). Maximizing corn productivity through different modern farming systems. Ph D. Thesis, Fac. of Agric., Mansoura Univ., Egypt.

Arif, M. ; F. Munsif ; M. Waqas ; I.A. Khalil and K. Ali (2007). Effect of tillage on weeds and economics of fodder maize production. Pakistan J. Weed Sci. Res., 13(3-4): 167-175.

Arif, M. ; M.T. Jan ; M.J. Khan ; M. Saeed ; I. Munir ; H.A. Shahenshah and M. Z. Khan (2011). Effect of cropping system and residue management on maize. Pakistan J. Bot., 43(2): 915-920.

Bezuidenhout, S.R. ; C.F. Reinhardt and M.I. Whitwell (2012). Cover crops of oats, stooling rye and three annual ryegrass cultivars influence maize and Cyperus esculentus growth. Weed Res., 52: 153-160.

Bharathi, S. ; R. Veeraraghaviah ; A.S. Rao and T.C.M. Naidu (2013). Influence of legume crops and fallows on fertilizer nitrogen requirement and productivity of succeeding maize-a review. Agri. Rev., 34 (1): 5061.

Dogan, M.N. ; A. Unay ; O. Boz and F. Albay (2003). Determination of optimum weed control timing in maize (Zea mays L.). Turkish J. Agric. For., 28 : 349 - 354.

Gardner, F.P. ; R.B. Pearce and R.L. Michell (1985). Physiology of crop plant. lowa State Univ. Press Ames. lowa. USA pp. 58-75.

Gomez, K.N. and A.A. Gomez (1984). Statistical procedures for agricultural research. John Wiley and Sons, New York, $2^{\text {nd }}$ ed., $68 \mathrm{p}$.

Kandil, E.E.E. and A.M. Kordy (2013). Effect of hand hoeing and herbicides on weeds, growth, yield and yield components of maize (Zea mays L.). J. of Appl. Sci. Res., 9(4): 3075-3082.

Khan, N.W. ; N. Khan and I.A. Khan (2012). Integration of nitrogen fertilizer and herbicides for efficient weed management in maize crop. Sarhad J. Agric., 3(28): 457-463. 
Lu, X. ; X. Lu ; X. Wen and Y. Liao (2015). Tillage and straw affect soil CO2 emissions in a rain-fed corn field. J. of Chemical and Pharmaceutical Res., 7(3):2353-2360.

Nassar, M.A.A. (2013). Response of new maize hybrid to biofertilization, soil nitrogen application and weed control. J. of Appl. Sci. Res., 9(1): 554-559.

Pedersen, P. and J.G. Lauer (2004). Soybean growth and development response to rotation sequence and tillage system. Agron. J., 96:10051012.

Snedecor, G. W. and W. G. Cochran (1980). Statistical Methods, $7^{\text {th }}$ Ed., Ames, IA: The lowa State University Press.

Takim, F.O. ; V. Awolade ; T.A. Ajisope and M.B. Lawal (2012). Evaluation of two new herbicide mixtures for weed control in maize (Zea mays L.). J. Environ. Iss. \& Agric. in Developing Count., 4(1): 71-78.

Wlaiwan, S. and H.P.W. Jayasuriya (2013). Effect of different tillage and residue management practices on growth and yield of corn cultivation in Thailand. Agric. Eng. Intern.: CIGR J., 15(3): 86-94.

Yeganehpoor, F. ; S.Z. Salmasi ; A. Solymani ; M. Valizadeh and F. Samadiyan ( 2013). Effects of hoeing and not hoeing of weed and using of companion plants on some agronomic traits of corn Sc 504. Intl. J. Agron. Plant Prod., 4(5): 1033-1039.

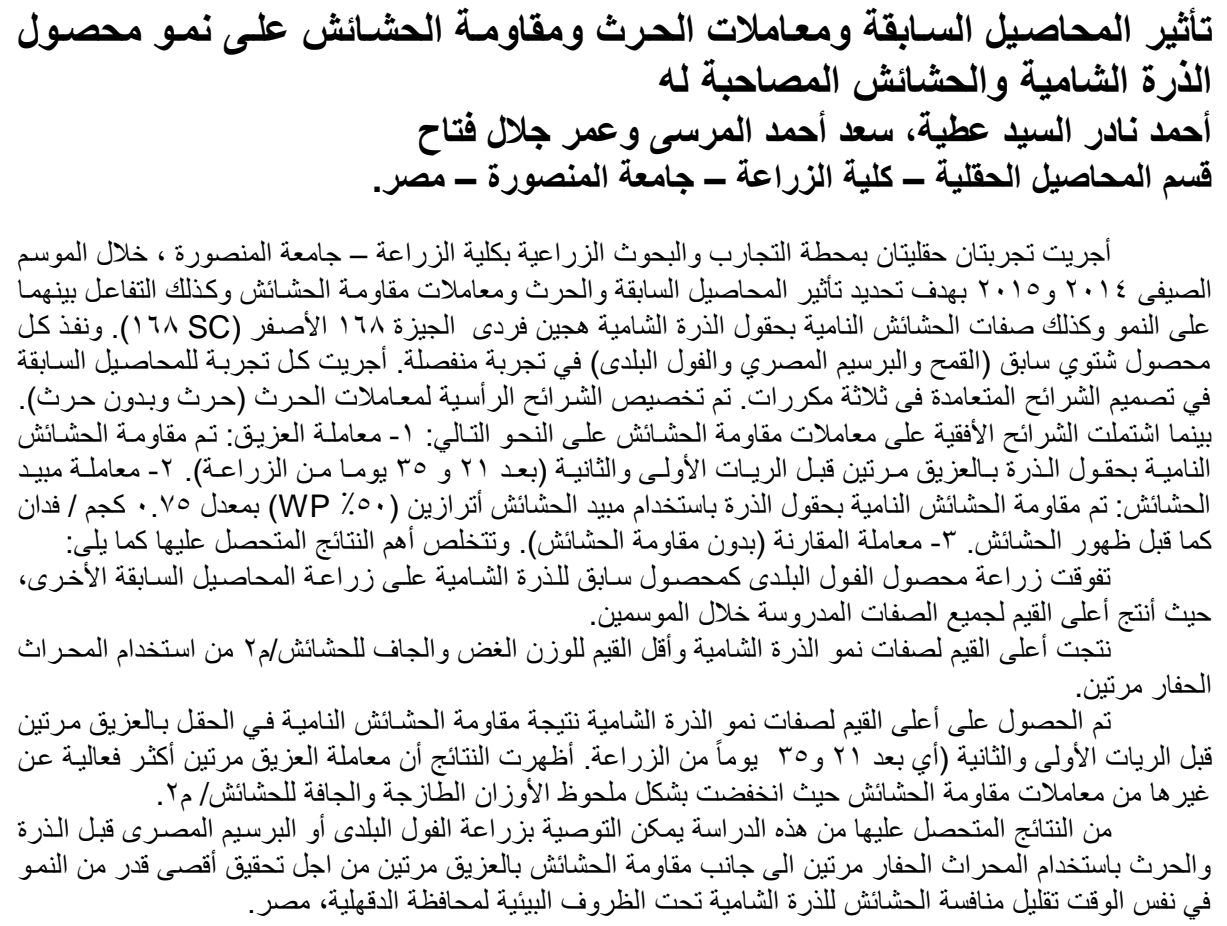

